\title{
The Time Machine? \\ Using Replica Analysis to Understand Merchant Ships and \\ the Development of the British Atlantic,1600-1800
}

\section{Phillip Reid}

Pour actualiser et élargir la perspective de l'histoire théorique sur la technologie des navires marchands européens, il faut analyser les idées associées à l'histoire des pays côtiers de l'Atlantique, l'histoire économique maritime, l'archéologie nautique, l'étude des cultures matérielles, l'histoire de la technologie et l'histoire technique des navires. La présente étude vise à compléter et à évaluer la recherche archivistique dans les documents officiels des marchands et des constructeurs de navires, ainsi que l'analyse technique des plans de bâtiment de navires existants à l'aide d'applications en architecture navale et en génie maritime. Proposant de recourir à des répliques de navires et aux expériences de ceux qui les exploitent, selon les méthodes de l'archéologie expérimentale, l'étude présente quelques résultats préliminaires. À la suite des connaissances déjà acquises, il est difficile de demeurer satisfait des suppositions héritées du passé au sujet de cette technologie sans procéder à de nouvelles enquêtes.

The history of the ordinary merchant ship from the Age of Discovery through the Age of Revolutions as presented in academic history consists largely of received wisdom and circular citations. ${ }^{1}$ Old books cite older books, few of which devote

\footnotetext{
${ }^{1}$ This article is based on a chapter of my doctoral dissertation, which in turn grew out of a paper presented at the 2015 annual conference of the North American Society for Oceanic History in Monterey, California in May 2015. It incorporates further research, thinking and discussion from that point up to April 2016. I am grateful to veteran ship archaeologists Nick Burningham and Fred Hocker for their thoughtful and thorough reviews of drafts of this paper and for their helpful, wise and stimulating comments, corrections, suggestions for further reading, and observations. I have tried to incorporate those into this version, and the paper is much the better for it. If I have not fully succeeded, that is solely my responsibility, and whatever provisional conclusions I present here are my own. This article presents one research approach among several used in the larger study. It relies heavily on the firsthand experience of period replica masters and crews, relayed directly to me either in written form or during recorded phone or Skype interviews. All of the transcripts and
}

The Northern Mariner/Le marin du nord, XXVI, No. 3 (July 2016), 299-316. 
much space to understanding the technology — including its human component without which the history being written would not have happened. ${ }^{2}$ To augment the scarce documentary and under-utilized archaeological source material, ${ }^{3}$ it seemed worthwhile to look for alternative sources of evidence to test received wisdom and to tackle an apparent paradox: How could a technology so often presented as static serve a world that was anything but?

One approach was inspired by experimental-archaeology efforts of the last few decades. This was to examine working replicas designed and built from all the evidence we do have, the documentary record, archaeological record, and iconography — on the strong hunch that the experience of designing, building, and operating such replicas could add to what our conventional sources offer. ${ }^{4}$ It would

recordings remain in my possession, and may be shared upon request, contingent upon the consent of the subject(s).

${ }^{2}$ For example, Ian Steele's book The English Atlantic, 1675-1740: An Exploration of

Communication and Community (Oxford: OUP) came out in 1986, and the technical authorities he references wrote in the 1970s and earlier. Ship histories from the 1920s and 30s are still cited in today's work - including mine.

3 Thanks to Dr Fred Hocker, director of research at the Vasa Museum in Stockholm, for pointing out in his comments on an earlier draft of this paper that the archaeological record contains examinations of "hundreds" of shipwrecks from this period, but that this record has not been adequately mined by "mainstream maritime history. Most of the interpretive archaeological work is European. More of that needs to be done on this side of the Atlantic, but colder, more anaerobic water conditions in northern Europe generally mean better-preserved wrecks to study.

4 I am using "replica" as a blanket term of convenience here; it can be useful to distinguish between a replica, which is based on near-complete data on a specific vessel and the materials and techniques used to build it, and a reconstruction, which is based on incomplete evidence gathered from whatever source material about similar vessels might be available, augmented by experiment and educated conjecture. For a concise introduction to these concepts, see Seán McGrail, "Experimental Archaeology: Replicas and Reconstructions," in Jenny Bennett, ed., Sailing Into the Past: Learning From Replica Ships (Barnsley UK: Seaforth, 2009), 16-23. By necessity, all seventeenth-century vessels considered here are reconstructions, as complete data for none of them are available. But some are based on more, and sometimes better, evidence than others. See Nicholas (Nick) Burningham, "Experimental Maritime Archaeology," in Claire Smith, ed., Encyclopedia of Global Archaeology (New York: Springer, 2014), 2717. For a recent precedent using replica and reconstruction experience to study problems in technological continuity and change in sailing vessels, see Julian Whitewright, "Technological Continuity and Change: The Lateen Sail of the Medieval Mediterranean," Al-Masāq 24:1 (April 2012), 1-19. This focus is neither to ignore nor disparage contemporary primary sources; we are fortunate to have some. Three of particular use on this topic are Edward Barlow, Barlow's journal of his life at sea in king's ships, East \& West Indiamen \& other merchantmen from 1659 to 1703, two volumes, transcribed by Basil Lubbock (London: Hurst \& Blackett, 1934); Samuel Kelly, edited by Crosbie Garstin, Samuel Kelly: An Eighteenth Century Seaman, (New York: Frederick A. Stokes Company, 1925); and Charles May, "An Account of the Wonderful Preservation of the Ship Terra Nova of London," in Churchill, Awnsham and John Churchill, Collection of Voyages and Travels, Some Now First Printed from Original Manuscripts, Others Now first Published in English, In Six Volumes, With a General Preface, giving an Account of the Progress of Navigation, from its first Beginnings, six volumes, third edition (London, 1747). As accounts intended for a general audience, these usually touch on technical matters only obliquely, but there are important exceptions. Of a thoroughgoing technical nature is Henry Mainwaring's The Sea-mans Dictionary : or, an exposition and demonstration of all the parts and things belonging to a shippe (1644), in G.E. Mainwaring, ed., 
allow meaningful comparisons of vessels separated by time, getting straight at the core duality of technological history - continuity and change. ${ }^{5}$

The literature agrees that changes in ship technology played a minor role in the increase in shipping productivity in the British Atlantic Empire. ${ }^{6}$ But this raises two questions. One, to the extent that the technology did not change, what does that tell us about the role this technology played? Henry Glassie, the pioneer of material culture studies and provocative critic of history, wrote: "Continuity more than change is the human condition. If organized around the goal of isolating variable, datable details, rather than around the goal of comprehending patterns of stasis and change, a discipline is doomed to the study of trivia."7 Nick Burningham wrote: "There is a tendency to see stasis in ship design as evidence of conservatism and even lack of intelligence - the medieval mind set from which science rescued us. It seems to me that design could change rapidly when necessary..." ${ }^{8}$ Fred Hocker also sees

a common problem in maritime history generally, which I think of as Victorianization, the tendency to assume that the last era of sailing ships before steam (Nelson's navy and clipper ships) represents the end of a long period of stasis, and that we can interpret the $17^{\text {th }}$ century as a backward

The Life and Works of Sir Henry Mainwaring, volume 2, (London: The Navy Records Society, 1920; e-reader edition published by The Internet Archive, 2007).

${ }^{5}$ Here, the primary inspiration is the work of ship historian, Smithsonian curator, and naval architect Howard Chapelle, especially The Search for Speed Under Sail, 1700-1855, originally published by Norton in 1967. See also his History of American Sailing Ships (New York: Norton, 1935); David MacGregor, Fast Sailing Ships: Their Design and Construction, 1775-1875

(Lymington UK: Nautical Pub. Co. 1973), and its sequel, Merchant Sailing Ships 1775-1815: Their Design and Construction (Watford UK: Argus Books, 1980).

6 See Douglass C. North, "Sources of Productivity Change in Ocean Shipping, 1600-1850," Journal of Political Economy 76:5 (September-October 1968); Gary M. Walton, "Obstacles to technical diffusion in ocean shipping, 1675-1775," Explorations in Economic History 8:2 (Winter 1970), 123-140; Christopher J. French, "Productivity in the Atlantic shipping industry: a quantitative study," Journal of Interdisciplinary History 17:3 (Winter 1987), 613-638; and James F. Shepherd and Gary M. Walton, Shipping, Maritime Trade, and the Economic Development of Colonial North America (Cambridge: CUP, 1972). For counterpoint, see Russell R. Menard, "Transport Costs and Long-Range Trade, 1300-1800: Was there a European 'transport Revolution' in the Early Modern Era?” in James D. Tracy, ed., The Political Economy of Merchant Empires (Cambridge: CUP, 1991), 262; and John McCusker, Essays in the Economic History of the Atlantic World (London: Routledge, 1997). Some economic historians focus more on technology; see Frederic C. Lane, «Progrès technologique et productivité dans les transports maritimes de la fin du Moyen Age au début des Temps Modernes», Revue Historique, nr. 251 (1974), 277-302; and Nathan Rosenberg, "Factors Affecting the Diffusion of Technology," Explorations in Economic History 10:1 (Fall 1972), 3-33. For important recent work, see the collection of essays edited by Richard Unger, who also contributes: Shipping and Economic Growth 1350-1850 (Leiden and Boston: Brill, 2011).

${ }^{7}$ Henry Glassie, Folk Housing in Middle Virginia: A Structural Analysis of Historic Artifacts (Knoxville: University of Tennessee Press, 1975), 75.

\footnotetext{
${ }^{8}$ Burningham, personal e-mail, 5 May 2015. Also see Lane, «Progrès technologique ...».
} 
extension of the $18^{\text {th }}$ and $19^{\text {th }}$. Archaeology shows that this is not the case. The sails of Vasa, for example, are nothing like the sails of Victory in their cloth or construction. ${ }^{9}$

Preoccupied with explaining rapid change and revolutionary technology, history has not paid much attention to the period between Magellan and Nelson as a technological age. But in truth, the global maritime world created at the instigation of Europeans between 1500 and 1800 was made possible by technology, and that technology did change throughout the period. It is worthwhile to understand how and why. We know there was technological change, so what was driving that?

We need to go beyond the literature to answer that question. But as we go aboard reconstructed vessels, or talk to those who sail them, we should keep in mind Ole Crumlin-Pedersen's caution: "Modern day social and mental constructs and limited relevant knowledge and skills, will inevitably impede our ability to replicate ancient vessels." ${ }^{10}$ Crumlin-Pedersen was a leader of the successful effort to reconstruct and test the recovered wrecks of Viking ships. And we may safely assume that by "replicate" he is not only referring to design and construction, but to techniques of operation. The challenges and opportunities of such an endeavour should become apparent in the ensuing discussion of actual experiences afloat.

John Kendrick repeats the common assumption that the older lateen mizzens were clumsy and eventually, logically replaced by gaff spankers, citing this as "great progress"; that the gaff spanker was "much easier to handle but also more effective for manoeuvring the ship." "B But Captain William T. "Chip" Reynolds, master of the replica Half Moon in New York has a different point of view, because he has commanded a vessel with a lateen mizzen. He wrote:

[Lateen mizzens] are so fundamentally different from other types of more modern sails used for tacking and maneuvering, that until one experiments with them, they seem cumbersome and ungainly. In fact, they are quite handy, elegant in their engineering, and practical in use. ...The forward yardarm could be warped over with better leverage (especially in high

\footnotetext{
${ }^{9}$ Hocker, personal communication, 19 August 2015.

${ }^{10}$ Crumlin-Pedersen, "Experimental archaeology and ships-principles, problems and examples," in Lucy Blue et al., eds., Connected by the Sea: Proceedings of the Tenth International Symposium on Boat and Ship Archaeology, Roskilde, 2003, (Oxford, 2006), 3.

${ }^{11}$ John Kendrick, "The Evolution of Shipbuilding in the Eighteenth Century, in Haycox, Barnett and Liburd, eds., Enlightenment and Exploration in the North Pacific, 1741-1805, (Seattle, and London: University of Washington Press, 1997), 95. For another traditional account of the evolution of lateen mizzen to gaff spanker, see G.S. Laird Clowes, Sailing Ships: Their History and Development, (London: HMSO, 1952), 67-68, and S.C. Gilfillan, Inventing the Ship, (Chicago: Follett, 1935), 60-61. Gilfillan attributes the major changes in our period to the old methods' being "sometimes harmful" and "rather useless." Clowes does not offer an explanation for the retention of the full yard with the cut-back sail, but John Harland does, in his indispensable Seamanship in the Age of Sail (Conway/Naval Institute Press, 1984), 75-76. (Thanks to Nick Burningham for pointing that out).
} 
winds), than by trimming the sheet. Further, the crew could do this from the deck rather than having to move aft with the officers. The full-length yard also balanced the weight of the spanker, thus, making it easier to rig the spar to the mast. ${ }^{12}$

Almost sixty years ago, naval architect and replica ship design pioneer William A. Baker wrote that tacking the mizzen was simpler than expected on his Mayflower $I I .^{13}$ Burningham wrote that "on Duyfken ...the mizzen was nearly useless, but would have been helpful in a few specific circumstances had we not been able to use the engines. The iconography shows very strongly that the lateen mizzen was hardly ever set." ${ }^{14}$ Captain Eric Speth, one of the most widely-experienced master of $17^{\text {th }}$ century replicas working, agrees with Reynolds that the mizzen is "handy," comparing favourably to the later gaff spanker, though he adds that it requires considerably more manpower to use on the replica English galleon Mayflower II, a larger ship, than it does on Godspeed or Discovery, the two smaller Jamestown replicas. ${ }^{15}$ The Duyfken experience at sea with the mizzen makes sense to him, and he confirms that the sail is a balancing and manoeuvring sail, and would be furled for downwind sailing — which is most of the sailing these ships did, Duyfken included - as it would move the centre of effort of the entire sail plan too far aft otherwise, making it more difficult to steer the ship on a steady track. ${ }^{16}$ And to Speth, the most sensible explanation for the retention of the full lateen spar is that the spar lent itself to counter-bracing to tack a ship in light winds or to tack a ship that did not tack well - a technique Speth has used often, and an explanation that jibes with Reynolds'. But, once staysails came into use, says Speth, that forward-projecting yard would have been in their way. Adding sails to a rig usually means making significant adjustments elsewhere so that those sails may be properly handled and

\footnotetext{
${ }^{12}$ Reynolds, personal e-mail, 5 February 2015. Half Moon, built in 1989 at Albany, New York, was intended as a reconstruction of Henry Hudson's vlieboot Halve Maen, in which he explored the northeast coast of North America in 1609.

${ }_{13}$ Baker, The New Mayflower: Her Design and Construction (Barre, MA: Barre Gazette, 1958), 117-118.

${ }^{14}$ Burningham, personal e-mail, 4 May 2015; and see Burningham, "Early Seventeenth-Century Ships," in Bennett, ed., Sailing Into the Past, 116. Duyfken, launched in 1999, is a replica of a VOC jacht launched in 1606, and one of the most carefully-researched and authenticallyconstructed period replicas ever made. Burningham worked on the Duyfken project and served aboard during her first ocean passages.

${ }^{15}$ Eric Speth, telephone interview, 14 August 2015. Capt. Speth has been maritime program manager, Jamestown-Yorktown Foundation, Virginia, for twenty-six years. Before that, he was in charge of the replica Maryland Dove at St. Mary's City. He has extensive experience on at least nine early seventeenth-century replicas and more on replicas representing later periods. Godspeed and Discovery are new (2006-2007) hypothetical replicas of the two smaller vessels in the Virginia Company trio that made the first landings in 1607 at what became Jamestown. They were based on years of careful and thorough research headed by Peter Wrike and Eric Speth.

${ }_{16}$ See the following discussion of tiller and whipstaff steering; Speth says the tiller and whipstaff are difficult to use if the sail plan is not correctly balanced. That is true of a modern wheel system on a modern yacht, so it stands to reason that it would be more true of these larger, heavier vessels. Speth, telephone interview, 14 August 2015.
} 
so that they - or other sails near them - receive clean wind, unblocked by neighbouring canvas. ${ }^{17}$ When ships grow larger, the spaces between their masts increase, but the sizes of individual sails are limited by the muscle power of the crew - and owners have a strong incentive to keep crew sizes the same while increasing capacity. Staysails can fill this increased space with drawing power, and as fore-andaft sails, mounted on fixed rigging already in place, they are not difficult to handle.

Captain Sharon Dounce of the Kalmar Nyckel, a larger ship than Reynolds' Half Moon or Speth's Jamestown ships, wrote that their mizzen provides balance for the sail plan when sailing close-hauled (into the wind), but that it is not used on a broad reach (off the wind) because it will then unbalance the sail plan. They use it for tacking the ship - coming through the eye of the wind bow-to-the-wind - but must douse it for wearing ship - coming through the eye of the wind stern-to-thewind. Their lateen mizzen "would likely have been shifted from side to side of the mizzen mast," which strikes her as "a pain in the neck, but with Vasa researchers, we practiced and timed it, as it fit into a tack." " So the lateen mizzen, odd and at first cumbersome to a modern professional sailor, is effective at its job, whether or not it would be the first choice of sailors with a subsequent two centuries' technological alternatives available.

For the most part, the same can be said of the earlier steering system of tiller and whipstaff. Ship historian Alan McGowan ties the adoption of the wheel to the adoption of the jib (triangular headsail), claiming that the wheel provided precise enough steering to allow maintaining control while sailing as close to the wind as the jib allows. ${ }^{19}$ McGowan's idea seems worth considering, but Burningham dismisses it: "Duyfken steers just a precisely as a wheel-steered ship with a good helmsman at the helm and just as badly with a poor helmsman." ${ }^{20}$ This suggests, strongly, that McGowan's interpretation needs testing.

We read that wheels replaced tillers and whipstaffs for steering after 1700 because wheels were so much easier and more effective to use, and authors muse about why it took so long to make that transition..$^{21}$ But replica masters report on the efficacy of the tiller and whipstaff, and technical ship history tells us that the technological impediments in the way of developing effective wheel steering were daunting and took a long time and many failed attempts to overcome. ${ }^{22}$ While it is

\footnotetext{
17 Speth, telephone interview, 14 August 2015.

18 Dounce, personal e-mail, 24 April 2015.Hocker is the head of those "Vasa researchers," and credit goes to Sharon Dounce for getting me in touch with him. Kalmar Nyckel is a reconstruction of the eponymous Dutch pinnace that brought the first colonists of New Sweden to North America. The reconstruction was launched at Wilmington, Delaware, in 1997, and is currently operating.

19 Losing control while sailing close-hauled could result in an accidental tack, damaging or destroying the rig, and probably wounding or killing crew, or cause the vessel to come to a sudden stop and lie helpless.

${ }^{20}$ Burningham, personal e-mail, 4 May 2015.

${ }^{21}$ To cite John Kendrick again, "steering was greatly improved by the belated invention of the steering wheel," 99.

${ }^{22}$ See John Harland, "The Early History of the Steering Wheel," Mariner's Mirror 58:1 (1972), 41-68.
} 
doubtless true, as Ian Steele writes, that wheel steering "dramatically increased rudder control on larger vessels" due to increased mechanical advantage - provided the system was functioning properly - it is important to know how much larger those vessels needed to be for that advantage to manifest itself, all other things being equal, if we are to understand the relationship between wheel steering and ship size. And the wheel offers advantages beyond the mechanical. Mounted on deck rather than below, it offers a less-restricted view for the helmsman, especially of the sails; with no deck over his head, the helmsman on a wheel-steered vessel can look up and see what the sails are doing while he steers. Hocker gives specific examples: "The limited view problem is acute in both Vasa and Kalmar Nyckel. In the former, the helmsman cannot see the horizon, so cannot judge if he is holding a straight course except by the compass, which is problematical due to the lag in compass movement. In $K N$, the helmsman cannot see the sails, so cannot be given a course such as 'full and by"". ${ }^{23}$ To what extent did that issue select for the adoption of the wheel?

The hypothesis that increasing vessel size was the imperative driving the installation of wheel steering for mechanical advantage is compelling. But Dounce and Reynolds pointed out, respectively, that the Swedish flagship Vasa and the big Dutch East Indiamen of the period were tiller-and-whipstaff-steered. ${ }^{24}$ Hocker says "Manwayring believed that the whipstaff was not useful on large ships, but the historical and archaeological evidence does not bear this out. Our calculations show that the whipstaff on $K N$ should take MORE effort to handle than that on Vasa, yet $K N$ can be steered in a storm by a small woman in her 70 s. ${ }^{25}$ Hocker points out that, while it is generally true that bigger ships require more steering effort and mechanical advantage, a larger tiller can provide that mechanical advantage — but "the large vessel will probably not have a tiller proportioned as well to its length" 26 - as the tiller would need to be too long to be practicable. This may have encouraged the adoption of wheel steering on larger vessels.

Turning to the jib, it is widely held that the increasing adoption of triangular jibs improved windward ability and ease of sail handling over the clumsy spritsail and sprit-topsail of earlier vessels. Yet replica crews report that, once they learned to use those earlier sails, they served to control the head of the ship and assist the rudder in steering her quite handily. This goes back to Alan Villiers and his transatlantic

\footnotetext{
23 Hocker, personal communication, 18-19 August 2015.

${ }^{24}$ Dounce, telephone interview, 23 April 2015; Reynolds, Skype interview, 8 January 2015. This issue is still under investigation.

${ }^{25}$ Hocker, personal communication, 18-19 August 2015. This comment also brings up the interesting complication of how to trust expert primary sources; Mainwaring (or Manwayring) was one of the most experienced and accomplished seamen of his day. As Hocker put it, "[t]his shows that there are areas where replica sailing may not only challenge the received wisdom of the secondary sources, but may reveal errors in perception in primary sources" (Hocker, personal email, 20 August 2015).

${ }^{26}$ Hocker, personal communication, 18-19 August 2015.
} 
voyage in Mayflower II in 1957. ${ }^{27}$ Villiers' experience is corroborated by Burningham from his experience aboard Duyfken; and of Kalmar Nyckel's spritsail, Dounce says it is difficult to balance the sail plan without it. ${ }^{28}$

It is clear that much of the specific skill set used every day on a seventeenthand early eighteenth- century vessel was lost even before the end of commercial sail. John Harland tacitly acknowledges this by rejecting the possibility that the sprittopsail remained in use as long as it did for reasons other than usefulness: "it is inconceivable that the seamen and shipbuilders of the day, as practical men, would have tolerated the consequences of poor design unless they saw, or thought they saw, some immediate advantage in so doing. However that may be, the oldfashioned spritsail topsail remains, in my view, pretty much an enigma." ${ }^{29}$ Experimental archaeology might get us closer to solving that enigma. Kalmar Nyckel has a sprit topsail, and Dounce reports that it does contribute to fine-tuning sail plan balance in light air, but that, while they have experimented with different ways to rig it, it is skill- and labour-intensive to use and requires care to set and douse, and that they do not use it very often. ${ }^{30}$

Crews of vessels like Australia's Duyfken, New York's Half Moon, and Mayflower II of Massachusetts, coming out of formative experiences with later sailing rigs, had to figure out how these earlier ships worked through trial and error. Reynolds, for example, said that when he first reported aboard Half Moon, having come out of an early twentieth-century topsail schooner, he was appalled by her rig, assessing it as "sloppy" and "inefficient," but soon came to appreciate it. ${ }^{31}$ But the original Half Moon was designed to be efficient as a long-distance sailer. Captain Walter Rybka of US Brig Niagara came out of an 1877 iron three-masted bark, designed and rigged for economical cargo transport, and when he reported aboard the replica War of 1812 brig, he guessed that, with her tall rig and light purchases intended solely for speed, power, and manoeuverability for short-term emergency service, she would be about 30 percent more work to sail, even though the two ships shared some basic dimensions. "I was absolutely dead wrong," Rybka says. "It was $200 \%$ more work." ${ }^{32}$

The aggregate of what we can learn so far from these replica masters, even before conducting formal experiments, is that it is not helpful to think of the earlier ships as better or worse than their successors. Pros and cons, advantages and disadvantages only have meaning in the specific context of the vessels' operating time and place. Early ships do not always strike their compromises in the same

\footnotetext{
27 Harland, Seamanship, 85; and "The Early History of the Steering Wheel," note 9, 65. Both pieces refer to Villiers' Give Me A Ship To Sail (New York: Scribner, 1959), 298. Also see Villiers, "How We Sailed the New Mayflower to America" National Geographic 92:5 (1957), 632. Villiers left us an important body of work based on his experiences in square-rigged vessels.

28 Burningham, "Learning to Sail the Duyfken Replica," International Journal of Nautical Archaeology 30:1 (April 2001), 78-79; Dounce, telephone interview, 23 April 2015.

29 Harland, Seamanship, 89.

30 Dounce, telephone interview, 23 April 2015.

31 Reynolds, Skype interview, 8 January 2015.

32 Walter Rybka, telephone interview, 21 April 2015.
} 
places as later ships, but they were well-suited to their tasks. If replica analysis cannot support the idea that some technologies were intrinsically superior to others in terms of performance, then we have even more motivation to look to all our sources for other reasons why specific technologies gained favour for use in specific situations.

Artisans built merchant vessels in this period. We have few plans for eighteenthcentury examples and none for the previous century. We have treatises on shipbuilding, but they were written by shipwrights or public officials involved in naval construction, either writing for an audience assumed to be well-versed in the craft or dismissive of what later authors saw as the outmoded and arcane ways of the traditional artisan and enamoured of the new "science," with its promise of universal principles and the opportunity to impose centralized, standardized control on ship design. ${ }^{33}$ Naval architects have pored over these treatises in their attempts to design replicas, and still found plenty to puzzle over. It is clear that the translation of ship design concepts to the builder's yard required the eye and experience of skilled craftsmen, who learned the trade as apprentices and journeymen. ${ }^{34}$ They might have known some basic math and some basic geometry, or not, but what made a good builder was the experienced eye. Eric Speth recounts that, when "legendary wooden boat builder" Jim Richardson was building the Maryland Dove replica on the Chesapeake Bay to a William Baker design, he would try to make changes to the design based on what his builder's eye was seeing as the ship took shape, and when Baker would visit for inspections, he would protest the changes. The eye of the experienced shipwright is still compelling. ${ }^{35}$

Document-based history is severely limited in conveying to us the nature of the artisan craft of ship design and construction. ${ }^{36}$ We need to build models — virtual

\footnotetext{
${ }^{33}$ For an introduction to this subject, see Larrie Ferreiro's Ships and Science: The Birth of Naval Architecture in the Scientific Revolution, 1600-1800 (Cambridge MA: MIT, 2006). For a concise, revealing summary of the attitudes surrounding the craft-versus-science issue, see N.A.M. Rodger, "Navies and the Enlightenment," in Pieter van der Merwe, ed., Science and the French and British Navies, 1700-1850 (Greenwich and London: National Maritime Museum, 2003), 9.

${ }^{34}$ Hocker pointed out that, with the exception of Sir Anthony Deane, who wrote his treatise for Samuel Pepys, treatises were written for those who already knew how to build ships, and that is why they leave out so much of the technical detail we would love to have (Hocker, personal communication, 18-19 August 2015).

${ }^{35}$ Speth, telephone interview, 14 August 2015. For modern studies of how artisanal craftsmen approach continuity and change in work boats, see Eric McKee, Working Boats of Britain: Their Shape and Purpose (London: Conway, 1983), with its important juxtaposition of specialization versus adaptability; and David A. Taylor, Boat Building in Winterton, Trinity Bay, Newfoundland (Ottawa: National Museums of Canada (Canadian Museum of Civilization, Mercury Series, Canadian Centre for Folk Culture Studies Paper Number 41), 1982), which focuses on a few specific, living builders and their boats.

${ }^{36}$ Two months in five archives examining merchants' and shipbuilders' papers in the summer of 2015 made that clear. Having said that, it is important to utilize the relevant documentary sources we do have. Insight into the lives and work of artisan shipbuilders may be found in some of those craftsmen's account books. A particularly useful one is the account book of David Lowell, 17811801, MSS 1229.1, Phillips Library of the Peabody-Essex Museum. For a concise appraisal of that source and of the importance of archival sources for the larger study, see Phillip Reid, "Looking
} 
and real - informed by material culture studies and archaeology, as Duyfken was; a replica is a full-scale model. While most replicas are not built using historically accurate techniques, tools and materials, the exceptions obviously have much more to teach us about how these ships were designed and constructed. ${ }^{37}$ Artisan culture, we know, tends to be quite adaptable and comfortable with borrowing and improvising. Authentic construction allows us to explore the influence of construction techniques and available materials on design characteristics, as the builders of the Duyfken learned when they set about building her the way they knew the original Dutch shipwrights had, using techniques shipwrights had not used in three centuries. ${ }^{38}$

The problem of hull design accuracy for the seventeenth-century replicas is compelling and instructive; differences in design approaches reflect different opinions about how the originals were built - opinions which have evolved over time but have not completely coalesced into consensus - and the different approaches throw into stark relief the challenges of interpreting the evidence. And because replicas are not usually built for experimental archaeology, historical accuracy of hull form is not always a high priority, even if the designers have a good idea of what that accuracy entails, and even if the regulatory apparatus allows such accuracy. But a design that does not accurately represent what it is supposed to may still offer valuable experimental data. Kalmar Nyckel has a hull that is "nothing like a Dutch pinnace of the 1620s," says Hocker. "[I]t is much more like an English frigate of the 1700s, with substantial deadrise, long entrance and run, etc. It thus does not handle like a pinnace. ${ }^{39}$ We are lucky that we know enough about Dutch pinnaces of the 1620s for Hocker to be able to say that, and we are also lucky that we can still use Kalmar Nyckel as a floating laboratory for learning about sail handling with $17^{\text {th }}$ century rigs and the handling characteristics of English frigate hulls of the 1700s. The replica may not be ideal, but she is still useful as long as we are responsible about interpreting what it is she has to teach.

Of prime importance in investigating hull design is stability. In almost every case, modifications to replicas have been made to increase inherent stability to meet current expectations for safety. Inherent is the key word here; vessels at the time depended much more on the stability created by loading and trimming. Our regulatory authorities demand that the stability they stipulate be built in to the vessel, including permanent ballast. But there is more to it than that. We are replicating technology developed by people who had starkly different notions of

for Ships in Boxes of Letters: Archival Research in Atlantic Maritime Technological History, 1600-1800," Conversant, the blog of the Phillips Library, 10 August 2015, http://www.pem.org /library/blog/?p=7692\#sthash.XAraZjaI.

${ }^{37}$ Timber availability restricts building options, just as it did then.

${ }^{38}$ For an account of building the Duyfken replica in Australia using early seventeenth-century Dutch artisan techniques, see Nick Burningham and Adriaan de Jong, "The Duyfken Project: an Age of Discovery ship reconstruction as experimental archaeology," International Journal of Nautical Archaeology 26:4 (November 1997), 277-292. For seventeenth-century Dutch techniques, see Albert Hoving, “The Fluit,” Nautical Research Journal 42:1 (March 1997), 24-35.

${ }^{39}$ Hocker, personal communication, 18-19 August 2015. 
acceptable risk, and who took very different things for granted than we do. We are on much surer footing if we assume that the standard for vessel stability of 1620 if that notion in this context is indeed anything but an anachronism - would have been significantly different from those recommended by today's marine engineers and imposed by the regulatory authorities of modern states. ${ }^{40}$

Dounce says that the replica Kalmar Nyckel's designers deliberately departed somewhat from the original in order to increase inherent stability. Speth reports that Stan Potter, naval architect for the current Susan Constant replica at Jamestown, did the same, and that Golden Hind in England has "blisters" on her hull for increased stability, as does Potter's Elizabeth II replica. ${ }^{41}$ Rybka of US Brig Niagara reports that his ship would have been "terrifying" to sail originally, and that they have heavily ballasted the replica both externally and internally and would not be sailing her otherwise. The Niagara is an extreme example, given that she was a warship built to contradictory imperatives - shoal draft, heavy armament, speed and manoeuverability, and accelerated construction - but her case adds to the aggregate evidence suggesting that original "standards of stability" are generally unacceptable to us - as are so many risks routinely taken by seventeenth- and eighteenth-century mariners.

Those mariners were themselves an integral component of the ship. When we consider the other mechanical force on the ship besides the wind and the water the humans setting and dousing sails, pulling on ropes, and moving the rudder we open another enlightening discussion. Indications are that the number of trained crew required to work the vessel is comparable for replica and original, though original crews would have been larger in the earlier ships to meet defensive needs and to provide a cushion for casualties to disease and armed conflict. While one might assume that the original crew was tougher and more inured to hardship than we are, one should also remember that they were much more likely to be malnourished, sick, and exhausted. What conversations with replica operators have reinforced is that the skill and experience of the crew are every bit as central to vessel performance as the primary source literature indicates. As Reynolds put it, referring to the difference in rudder design between earlier and later ships, "you're not going to be able to use the technology to compensate for lack of skill." 42 On the other hand, Dounce pointed out how much useful work could be done on Kalmar Nyckel with unskilled or semiskilled labor. With the simple rig and simple direct

\footnotetext{
${ }^{40}$ Contemporaries did, however, recognized stability problems, and Jonathan Adams presents evidence that typical hull form was already changing in the direction of increased inherent stability by 1620. See Adams, A Maritime Archaeology of Ships: Innovation and Social Change in Medieval and Early Modern Europe (Oxford, UK and Oakville, CT: Oxbow Books, 2013), 111151.

${ }^{41}$ Speth, telephone interview, 14 August 2015. Susan Constant is the 1989 reconstruction of the largest of the Jamestown settlement trio. The original Golden Hind was Sir Francis Drake's circumnavigation flagship, 1577-1580. Elizabeth II is a reconstruction not of a particular vessel but intended to represent the small English ships sent in 1582 and 1587 to attempt settlement in what is now North Carolina.

${ }^{42}$ Reynolds, Skype interview, 8 January 2015.
} 
steering system, even untrained passengers can haul on a line to move a sail, and even a new helmsperson can feel what the whipstaff is doing to the rudder angle. Her experience with this has helped her understand how the original vessel could function with conscripted landsmen, which they know she carried. ${ }^{43}$ Given the perpetual shortage of skilled seamen in this period, lowering the required aggregate skill set would have been advantageous in that respect. In terms of expertise, it may be that modern replica crews, if they are experienced enough, have better-developed skills in general than their original counterparts. From his experience on the Kalmar Nyckel, Hocker writes: "Because Kalmar Nyckel completes a passage once or twice every day of the sailing season, leaving the dock, setting sail, tacking and wearing, striking sail, and returning to the land, the crew of that ship have accumulated more actual sail handling experience with this rig than any seventeenth-century sailor ever did, since they spent more time in port and were engaged in longer passages with minimal changes to sail set." 44

That is not to suggest that the original sailors did not know how to do things that we no longer know how to do the same way. That is what much of the on-board experimentation is about - trying to figure out how best to perform operational tasks, assuming that the original sailors would have figured out the same things over time. ${ }^{45}$ What replica experience can teach us is how many able-bodied adult humans it takes to operate a certain vessel rigged a certain way in certain conditions. If we are confident in the accuracy of a replica, we can compare that number to the number of crew known to have served on a similar vessel originally, and if there is a difference, begin to explore why that might be.

This approach to gathering experiences on replicas is a makeshift form of experimental archaeology, which has a history and a methodology, both inside and outside the maritime world, going back to the $1960 \mathrm{~s} .{ }^{46}$ According to a large group of co-authors from archaeology and history who wrote an article on the subject twenty years ago, the ideal first step in using a replica vessel for experimental archaeology is to build it exclusively and specifically for use in experimental archaeology. ${ }^{47}$ But this is the real world, and in the real world, multi-million dollar

\footnotetext{
43 Dounce, telephone interview, 23 April 2015.

44 Hocker, personal communication, 18-19 August 2015.

${ }^{45}$ Captain Daniel S. Parrott casts a harsh light on the urgent and dangerous imperative of reacquiring lost seamanship skills to operate period vessels when he considers the issue in the context of disasters involving sail-training vessels in the late $20^{\text {th }}$ century. See Tall Ships Down:

The Last Voyages of the Pamir, Albatross, Marques, Pride of Baltimore, and Maria Asumpta, (Camden ME: International Marine/McGraw-Hill, 2003).

${ }^{46}$ See Seán McGrail, "Replicas, reconstructions and floating hypotheses," International Journal of Nautical Archaeology 21:4 (November 1992), 353-355, for an argument supporting this sort of endeavor by a prominent maritime archaeologist. Also see Burningham in Smith, ed., Encyclopedia, 2717.

47 John Coates, et al., "Experimental Boat and Ship Archaeology: Principles and Methods," International Journal of Nautical Archaeology, 24:4 (November 1995), 293-301. Also see Burningham in Smith, ed., Encyclopedia, 2716-2718.
} 
replicas are not ever built exclusively for experimental archaeology ${ }^{48}$ — though they may be, and have been, built with the declared intent of being used for that purpose — among others. ${ }^{49}$ Burningham writes,

The Duyfken project could not be justified purely in terms of its operation as an informative museum display and neither could its cost be justified in terms of the program of experimental archaeology that its construction and sailing are intended to be. Sailing ships get built or preserved for a whole range of reasons that have a lot to do with celebration of shared history and their ability to capture the popular imagination. Sailing ships symbolise adventure, daring, escape and freedom of the seas, independence, voyages of discovery, treasure, the origins of the nation, international contact, and there is also the widely perceived value of sail training, for young people in particular. $^{50}$

Replica ships have to be able to represent their world and function in ours at the same time. Like every ship ever built, every replica is a set of compromises.

Replicas are built primarily for education, and in order to pay their bills, they need to carry paying passengers and support hordes of dockside visitors. In order to do that, they have to meet stringent modern governmental safety standards that were unheard-of when the originals were built. Replicas carry auxiliary power, so they can get where they need to be regardless of the wind's caprice, and so they have propellers sticking out of their sterns. They are not ballasted the way the originals were; they carry water tanks, fuel tanks, waste tanks, engines - all heavy, and all down low, out of sight; weight is not spread vertically as it would have been in the

\footnotetext{
${ }^{48}$ Ole Crumlin-Pedersen listed nine reasons why replicas and reconstructions are built, only one of which is research. See "Experimental archaeology and ships_-principles, problems and examples," in Blue et al., Connected by the Sea, 3.

${ }^{49}$ See Timm Weski, "The value of experimental archaeology for reconstructing ancient seafaring," in Blue, et al., Connected by the Sea, 63-67. I think Weski is missing more than one important point, including this one: that full-scale replicas of large ships are never built or operated solely as archaeological experiments, so that to some extent, pointing out that what we can learn from them may not justify their expense, and that some things we can learn from them we could perhaps learn from models or smaller-scale replicas, is neither here nor there.

${ }^{50}$ Burningham, "Tallships and Replicas," http://www.austlii.edu.au/au/journals/MarStudies/2000/3.html, accessed 5 May 2015.
} 
original vessel. ${ }^{51}$ They do not carry cargo the way the originals did. ${ }^{52}$ Some use synthetic materials and in most cases modern construction techniques so they will last far longer than the originals did, providing a much-needed return on investment for the non-profit organizations who build them, and because the timber used in the originals is no longer available. ${ }^{53}$ But synthetic sails and rigging perform differently from the original organic materials. Hocker points out that synthetic sailcloth and rigging are "stronger and more aerodynamically efficient" than their organic original counterparts. ${ }^{54}$ So, for experimental-archaeology purposes, we would do well to either equip our replicas with natural-fibre sails and rigging as close to the originals as we can get, or at least take into account the differences between the performance of the originals and synthetic reproductions in any evaluations of vessel performance. The Swedish Ship Götheborg has hemp rigging and flax sails, so that the experience of sailing her would be as close to the original as possible. Joakim Severinson, her master shipwright, reports that the hemp standing rigging "moves more than ... wire rigging. But we also noticed that this type of rigging is more adjustable than ... wire rigging with fixed yards." 55 So there is a specific advantage and disadvantage; the more of those we discover, the easier we can demolish simplistic assumptions about what is "better" and what is "progress."

In important ways, the history of the design, construction, and operation of replicas is a history of what we have learned about the originals. ${ }^{56}$ There is nothing like having to recreate the thing to force all the questions we might otherwise miss into the fronts of our brains, to weigh sometimes-contradictory evidence, and to justify to other people the judgment calls we make to get the project done.

The foregoing accounts of experiences on replica vessels represent the preliminary phase of an investigation that must now turn to more formalized and structured experiments to proceed. But even these first steps raise questions, and hint at answers, that challenge received wisdom and make it more difficult for us to make

\footnotetext{
${ }^{51}$ It is important to distinguish between internal and external ballast when considering possible effects of differences in ballasting on replica vs. original performance. Internal ballast may affect trim and motion differences, which are important, or it may not. External ballast will definitely affect windward ability and leeway, making major differences in performance. For example, when first built, the current Niagara replica made exactly the same leeway as her original sister ship $-18^{\circ}$. When fitted with her current external lead ballast, which projects downward from the garboard thirty inches, she made $7^{\circ}$. That is a drastic difference (Rybka, telephone interview, 21 April 2015).

${ }^{52}$ It is worth considering that the amount of ballast these replicas normally require and their full lines and much bluffer bows than modern sailors are accustomed to remind us that they were built to carry cargo, and as much of it as possible for their size.

${ }^{53}$ Most replicas make use of laminated frames and spars: "about the time we ran out of good trees, we invented good glue” (Rybka, telephone interview, 21 April 2015).

${ }^{54}$ Hocker, personal communication, 18-19 August 2015.

55 Joakim Severinson, personal communication, 19 March 2015. Severinson is the master shipwright of the Götheborg.

56 The clearest example of this is probably the Jamestown fleet, three sets of which have now been built and operated, beginning in the 1950s with the latest vessels built in 2006-2007. The most comprehensive compilation of information on this history is probably Peter Wrike's research report. For an easily accessible digest, see Wrike in Bennett, ed., Sailing Into the Past, 120-133.
} 
sweeping generalizations about technological continuity and change. For each of the technical foci of this paper, some experiments would be useful.

For the mizzen sail, to confirm Speth's idea that the adoption of staysails would have contributed to the abandonment of the lateen mizzen yard might only require manipulating a model fitted with both. Second, replica sailing can give us an idea of manpower requirements for using similarly-sized lateen mizzens, cut-back lateen mizzens, and gaff spankers, which might provide insight as to why they occurred in history in that order. And finally, we could compare labour requirements for the same sail on different-sized vessels, to advance the investigation of the implications of vessel size for design and rig. Speth reports that more labour is required to use Mayflower II's lateen mizzen than on his smaller ships. But how much more? If we could conduct such experiments in similar wind and sea conditions, we could add to our understanding of actual manpower requirements for working the vessel, as opposed to the number of crew a vessel actually carried.

Hocker's observations about tiller length make the wheel versus the tiller-andwhipstaff issue more complex. Given that the earlier system was employed on some of the largest ships of the entire period, the choice of one or the other cannot be explained by size alone. But given also that tillers remained in use on smaller vessels into our own time, size was clearly a factor. We may do no better than a comparative study of the operation of both systems on a variety of trustworthy replicas in real world conditions, compiling experiences and observations on the advantages of one system on a particular vessel and how the other system might perform comparatively. The goal would be a better understanding of the imperatives driving the ultimate ubiquitous adoption of the wheel system on middling and large vessels.

On the question of headsails, further experiments of the kind Dounce described on the Kalmar Nyckel with the sprit-topsail can only add to the little we understand about this mysterious device. If it was tricky to rig and trim, and labour intensive, why did it persist so long when triangular sails mounted on head-stays were already in use? It would also be useful to compare how the same vessel performs with and without triangular jibs. Those sails were contemporaneous with the older spritsail throughout the period, so it's unlikely that they superseded that sail entirely. We do not need experiments to know that a triangular jib would be more useful for going to weather than a sprit-topsail. But we could use experiments to help determine how much that really mattered.

We can only make progress in our understanding of hull design through archaeology; the written record is inadequate, and iconography rarely depicts anything below the waterline. Duyfken and Götheborg, both based extensively on substantial archaeological remains, among other things, are promising; we can trust what they have to teach us about stability, resistance, manoeuverability, capacity, and seaworthiness if we take into account differences in lading and ballasting. Government regulations are less strict for vessels that do not carry passengers for hire; any opportunity to load and ballast a vessel authentically for experiments, 
crewed by volunteers, would certainly be worth seizing. ${ }^{57}$

The stability problem discussed earlier is as compelling as any raised in this study. How much of the stability issue with replicas is due to our correct reproduction of unstable original designs, and how much of it is attributable to our loss of the invisible process by which a "design" was translated into a ship — a process the treatises cannot accurately convey to us? Analysis of actual archaeological remains, and methodologically valid experiments (whether with models or replicas) based on those, is the way forward. But it is worth remembering that cultural history has already offered us something invaluable here; the standards, expectations, and values of a different culture than our own would surely guide the production and use of a different sort of technology than what we would make. In fact, we would do well not to lose sight of the forest for the trees; we would never build nor use the ships we are studying here at all, except for the specific purpose of reconstructing and understanding a relic.

Side-by-side sailing trials of vessels with different hull designs allow us to sidestep time. Although it is exceedingly difficult to isolate individual factors contributing to differences, if we can actually experience how two very different vessels from different times compare in the same conditions, we can at least dispel common tacit assumptions and move toward more useful apprehensions of comparative reality. When conducting sea trials with the current Godspeed in Penobscot Bay, Maine, Speth took some of the builders and shipyard staff out. They were accompanied by some of the similarly sized late nineteenth- and early twentieth-century schooners still common in those waters. People were surprised, he remembered, at how Godspeed sailed, how she carried sail, and how weatherly she was, ${ }^{58}$ with the qualification of course that she was a square-rigger and thus could not stay on a windward tack as long as a schooner. He once had Maryland Dove out in the Chesapeake Bay and sailed her with the extreme schooner (Baltimore clipper) Pride of Baltimore, and in the right conditions could keep up with her, even with 30-40 percent less waterline and much less sail area. ${ }^{59}$ And these early seventeenth- century ships are full-bodied, capacious carriers, intended to load as much as possible for their size without compromising sailing ability too much. That "too much" is the hard part for us — what does that mean, for those people in that time? Sailing these ships together helps us answer that question; it seems to mean that performance was at least roughly comparable to ships with much sharper lines, much less capacity, and much more labour-intensive and damage-prone rigs. And if Maryland Dove could keep up with Pride of Baltimore in some conditions, that also helps us to understand why we see as little variance in passage times in the

\footnotetext{
57 An example of such a vessel is the original Pride of Baltimore, lost in 1986. There are critical safety considerations here, though-see Parrott.

58 Another challenge to the conventional wisdom, repeated by Kendrick, that the earlier squareriggers "could make little if any progress against the wind" 91.

59 Speth, telephone interview, 14 August 2015. Maryland Dove is a reconstruction of one of the two merchant ships that made the first English expedition to what became Maryland, 1632-1634. The William A. Baker design was launched in 1978.
} 
age of sail as we do; what these vessels could do was, generally, dictated by conditions, rather than by their own intrinsic qualities. Those qualities, indeed, are best shaped to give the vessel the best chance of surviving those conditions and getting her crew and cargo where they are going.

The more such side-by-side sailing of vessels with different hulls we do, the better. We can carefully set about trying to isolate variables such as load and sail area when comparing their performance, but the more obvious differences are just as important - how close to the wind can each one get? How close are their speeds on the same broad reach? How is the motion? One day of such trials can generate so much information to consider, as nothing else can.

There are also some questions to investigate with respect to the human component of the technology. How many able-bodied adults does it take to trim the lateen mizzen on a beam reach in twenty knots of wind? How about the same trial on a vessel similarly-rigged but $\mathrm{X}$ percent larger or smaller? How about one equipped with a lateen mizzen yard but with a cut-back mizzen sail? How about one with a more modern gaff spanker?

Can we compile data on number of crew it takes to actually operate a vessel on a voyage from port to port with and without defensive capability? We know how to work those ships and we know how to work those weapons. And then do the same for a number of vessels? We could cross-reference those numbers with the numbers Ralph Davis ${ }^{60}$ compiled and re-enter the discussion of how much the increase in tons-per-man over time was attributable to increased security - the point that so compelled North, Shepherd and Walton.

The human component is a core component of all the experiments proposed above. We are unlikely to find any one factor guiding continuity and change in ship technology in our period more firmly than labour requirements.

That leads us to provisional conclusions - perhaps better-described, in scientific language at least, as theories to be further tested. Here, we move from specific technical detail back toward larger historical questions.

Once we have established a solid argument that certain differences in vessels used for the same purposes in the earlier part of the period and the later part of the period are typical, do these differences give the later vessels any absolute advantages in capability that a naval architect would point to? Is there something here that we would call technological "progress"? If so, what? The evidence on rigs, sails, and ship handling so far suggests that any such advantages have to do with maximizing labour efficiency. The best hypothesis to explain changes here is still increasing size, for which we have the evidence, going back to Davis. Hull design continuity and change are probably also related to labour, in that increased capacityfor-size, toward which archaeology and maritime economic history both point,

\footnotetext{
${ }^{60}$ Ralph Davis, The Rise of the English Shipping Industry in the Seventeenth and Eighteenth Centuries (London: Macmillan, 1962). Reprinted in 1972 with a new introduction by the author, and again by The International Maritime Economic History Association in 2012 in its Research in Maritime History series, with an introduction by Lewis R. Fischer and David M. Williams.
} 
means higher ton-per-man ratios. We need to compile as much evidence as we can to test the idea of an overall trend toward increased capacity-for-size. Here, replica analysis may play a more secondary role than it can in ship handling and manning questions. If we could be confident of a replica's hull design accuracy, and load and ballast that hull authentically, we could evaluate that hull's sailing characteristics vis-à-vis those of an earlier or later authentic replica. Barring that, an experimentalarchaeology contribution to this particular aspect may elude us.

The stability component of hull-design analysis will require engineering-lab analysis of original and trustworthy replica plans. Increased stability may well be a general trend over the period; if so, was there a price for that, or was it an absolute gain ${ }^{61}$

The over-arching question remains: how well did this technology serve a rapidly and aggressively growing, competitive, restless maritime empire, dependent on adaptable networks of long-distance waterborne communication and a fleet of ships that could spread risk as well as profit to keep that competitive growth moving? The size increases Davis found are modest. This cannot be surprising as it spreads risk better to build more smaller ships rather than fewer significantly larger ones. The changes made to the technology over the course of the period were, on aggregate, much closer to minor tweaks than re-inventions. Was it the case that the basic technology served well enough that fairly minor adaptations and the ability to build more of them as needed got the job done?

It would seem that the ordinary Atlantic merchant ship served its world well; that the continuity of the technology in the period makes sense- - the technology was not a limiting factor in the development of the British Atlantic. If further investigation can support that theory, it will have done justice to Glassie's maxim. The changes may present more of a challenge to understand. It is not much of a stretch to assume that these people would have adapted their technology to better meet changing needs as necessary. So how can understanding these technological changes help us better understand what those needs were? Of all the questions such a study as this might help to answer, none is more important than that one.

\footnotetext{
${ }^{61}$ There was certainly a price for insufficient stability, even if the vessel remained in service - "furring" or "girdling," in which an extra layer of planking was attached to the hull to increase breadth, especially around the waterline. This was obviously an extra cost in materials and labour.
} 